DOI: $10.19195 / 0137-1134.114 .40$

\author{
ANDRZEJ POWAŁOWSKI \\ Uniwersytet Gdański \\ anpo@prawo.ug.edu.pl
}

\title{
AKSJOLOGIA I PRAWO PRZEKSZTAŁCEŃ WŁASNOŚCIOWYCH W GOSPODARCE
}

\begin{abstract}
Abstrakt: Przekształcenia własnościowe mają charakter głównie podmiotowy, polegają bowiem przede wszystkim na ,zastępowaniu” określonych podmiotów prawa własności innymi. Przekształceniami własnościowych są nacjonalizacja i będące jej konsekwencją i niejako odwrotnością: reprywatyzacja, uwłaszczenie, komunalizacja i prywatyzacja. Każda z tych postaci wiąże się z podejmowaniem czynności prawnych i faktycznych, których celem jest wywołanie odpowiedniej zmiany podmiotu prawa własności. Podstawą tych działań są akty prawne rangi ustawy, wprowadzające obowiązek — aktualizowany w toku odpowiedniej procedury — przejęcia prawa własności od dotychczasowego właściciela (właścicieli). W każdym przypadku dokonania przekształcenia własnościowego formułowane są — w sposób wyraźny lub dorozumiany — przesłanki lub cel przekształcenia, w szczególności interes publiczny, któremu nadawane są zróżnicowana treść i znaczenie. Jednak nie tylko ogólnie pojmowany i nie zawsze wyraźnie określany interes publiczny jest przesłanką dokonywania przekształceń własnościowych. U podstaw owych przekształceń leżą też różnego rodzaju wartości zarówno o charakterze prawnym, jak i ekonomicznym i społecznym, a w konsekwencji rozmaite mogą być motywy (przesłanki) ich dokonywania.
\end{abstract}

Słowa kluczowe: przekształcenia własnościowe, nacjonalizacja, reprywatyzacja, komunalizacja, uwłaszczenie, prywatyzacja, interes publiczny

\section{WPROWADZENIE}

Podstawą różnorodnych relacji zachodzących w gospodarce między jej podmiotami a podstawą oddziaływania państwa na gospodarkę jest własność i związany z nią ogół praw i będące ich przedmiotem składniki majątku zaangażowane w działalność gospodarczą. Istotne znaczenie dla funkcjonowania gospodarki mają, będące postacią interwencjonizmu państwowego, inspirowane przez państwo i dokonywane przez jego organy przekształcenia własnościowe w gospodarce wyznaczające jej strukturę własnościową i budujące pozycję poszczególnych sektorów własnościowych ${ }^{1}$. Przekształcenia własnościowe mają charakter głów-

${ }^{1}$ Zob. w tej kwestii A. Powałowski, Przekształcenia własnościowe w gospodarce jako przejaw interwencjonizmu państwowego, „Gdańskie Studia Prawnicze” 22, 2009, s. 27 n. 
nie podmiotowy, polegają bowiem przede wszystkim na „zastępowaniu” określonych podmiotów prawa własności innymi; w zdecydowanie mniejszym stopniu dotyczą praw i obowiązków związanych z wykonywaniem własności. Przekształceniami własnościowymi są nacjonalizacja i będące jej konsekwencją i niejako odwrotnością: reprywatyzacja, uwłaszczenie, komunalizacja i prywatyzacja. Łączy je wiele cech wspólnych. Najpierw należy nadmienić, że każda z tych postaci wiąże się z podejmowaniem czynności prawnych i faktycznych, których celem jest wywołanie odpowiedniej zmiany podmiotu prawa własności. Podstawą tych działań są akty prawne rangi ustawy, wprowadzające obowiązek — aktualizowany w toku odpowiedniej procedury — przejęcia prawa własności od dotychczasowego właściciela (właścicieli). W każdym wypadku dokonania przekształcenia własnościowego formułowane są — w sposób wyraźny lub dorozumiany — przesłanki lub cel przekształcenia, w szczególności interes publiczny, któremu nadawana jest zróżnicowana treść i znaczenie. Jednocześnie trzeba dostrzegać, że powołanie się na interes publiczny może mieć miejsce również w sytuacji, w której państwo powstrzymuje się od interwencji w sferę prawa własności i stosunki własnościowe kształtuje przy wykorzystaniu instrumentów cywilnoprawnych.

Jednak nie tylko zazwyczaj ogólnie pojmowany i nie zawsze wyraźnie określany interes publiczny jest przesłanką dokonywania przekształceń własnościowych. U podstaw owych przekształceń leżą różnego rodzaju wartości o zarówno charakterze prawnym, jak i ekonomicznym i społecznym ${ }^{2}$, a w konsekwencji różne mogą być motywy (przesłanki) ich dokonywania.

\section{NACJONALIZACJA}

Pierwsza z postaci przekształceń własnościowych — nacjonalizacja — to proces, jaki miał w Polsce w latach czterdziestych i pięćdziesiątych XX wieku. Nacjonalizacja - sprowadzająca się do przejęcia przez państwo od osób prywatnych i instytucji pozapaństwowych prawa własności — obejmowała swym zakresem wiele składników majątkowych, w tym przedsiębiorstw, nieruchomości ziemskich, aptek, fundacji, taboru żeglugi śródlądowej, dóbr kultury, lasów, dóbr kościelnych, kapitału zagranicznego, gruntów warszawskich, a także majątku komunalnego ${ }^{3}$.

${ }^{2}$ Zob. w tej kwestii A. Powałowski, Wybrane zagadnienia filozofii prawa gospodarczego publicznego, „Gdańskie Studia Prawnicze” 18, 2007, s. 289 n.

3 Zob. np. ustawa z dnia 3 stycznia 1946 r. o przejęciu na własność Państwa podstawowych gałęzi gospodarki narodowej (Dz.U. Nr 3, poz. 17 ze zm.); dekret z dnia 6 września 1944 r. o przeprowadzeniu reformy rolnej (tekst jedn. Dz.U. z 1945 r. Nr 3, poz. 13 ze zm.); dekret z dnia 24 kwietnia 1952 r. o zniesieniu fundacji (Dz.U. Nr 25, poz. 172 ze zm.); dekret z dnia 2 lutego 1955 r. o przejęciu taboru żeglugi śródlądowej na własność Państwa (Dz.U. Nr 6, poz. 36 ze zm.); ustawa z dnia 18 listopada 1948 r. o przejściu na własność Państwa niektórych lasów i innych gruntów samorządowych (Dz.U. Nr 57, poz. 456); ustawa z dnia 20 marca 1950 r. o przejęciu przez Państwo dóbr martwej 
W wyniku nacjonalizacji powstał niezwykle rozbudowany, obejmujący wiele składników majątkowych sektor państwowy, a jego udział w całej gospodarce narodowej przekraczał 70\%. Co charakterystyczne, to nie Skarb Państwa, lecz samo państwo stało się podmiotem tak zwanego mienia ogólnonarodowego. Zaznaczał to (od 1964 roku) kodeks cywilny, w art. 128 wskazując, iż własność państwowa przysługuje niepodzielnie państwu. W rzeczywistości zatem oraz de iure państwo stało się podmiotem prowadzącym działalność gospodarczą na szeroką skalę i ponoszącym konsekwencje związane z tą działalnością, a to głównie za sprawą słabo zaznaczonego wyodrębnienia państwowych jednostek organizacyjnych oraz ich znikomej odpowiedzialności prawnej i faktycznej.

Nacjonalizacji dokonano ex lege $e^{4}$ z tym jednak, że w wypadku nieruchomości niezbędne było wydanie przez odpowiedni organ administracji publicznej decyzji o charakterze deklaratywnym ${ }^{5}$, stanowiącej podstawę wpisu nowego właściciela do księgi wieczystej faktycznego przejęcia nieruchomości i wypłaty odszkodowania ${ }^{6}$.

Co do swego charakteru nacjonalizacja była przymusowym, władczym przejęciem mienia od osób prywatnych i innych (pozapaństwowych) jednostek organizacyjnych. Pomiędzy dotychczasowymi właścicielami a państwem nie doszło do zawarcia w tej kwestii żadnego porozumienia, lecz do jednostronnej ingerencji państwa w sferę stosunków własnościowych, w której wyniku państwo nabyło prawo własności w sposób pierwotny ${ }^{7}$, a więc — jak zaznaczono - bez jakichkolwiek obciążeń względem osób trzecich. Zastrzeżono jednak, że państwo może przedsiębiorstwa przejęte na własność prowadzić we własnym zarządzie bądź przekazywać je samorządowi terytorialnemu lub spółdzielniom albo ich związkom na zasadzie uchwały Rady Ministrów.

W dobie kryzysu finansowego i gospodarczego w różnych krajach nacjonalizacja przybiera postać głównie „kapitałową” i sprowadza się do przejmowania przez państwo akcji spółek kapitałowych, a zarazem kontroli nad poszczególnymi instytucjami finansowymi i przedsiębiorcami. W tym ujęciu nacjonalizacja jest przede wszystkim środkiem zmierzającym do zapobieżenia upadłości różnego

ręki, poręczeniu proboszczom posiadania gospodarstw rolnych i utworzeniu Funduszu Kościelnego (Dz.U. Nr 9, poz. 87 ze zm.); dekret z dnia 26 października 1945 r. o własności i użytkowaniu gruntów na obszarze m.st. Warszawy (Dz.U. Nr 50, poz. 279 ze zm.). Wszystkie wymienione akty prawne zachowują formalnie moc obowiązującą, gdyż nie zostały uchylone.

4 Tak art. 1-2 ustawy o przejęciu na własność Państwa podstawowych gałęzi gospodarki narodowej.

5 Pojawił się jednak problem wadliwości tego rodzaju decyzji; zob. R. Trzaskowski, Nieodwracalne skutki prawne wadliwej decyzji nacjonalizacyjnej. Przedstawienie dorobku orzecznictwa i doktryny, „Kwartalnik Prawa Publicznego” 2003, nr 3, s. 9-56.

${ }^{6}$ Przy ustalaniu wysokości odszkodowań należało uwzględniać między innymi tak zwane ogólne obniżenie wartości majątku narodowego oraz obniżenie tej wartości na skutek działań wojennych — tak ustawa o przejęciu na własność Państwa podstawowych gałęzi gospodarki narodowej.

7 Zob. J. Ignatowicz, K. Stefaniuk, Prawo rzeczowe, Warszawa 2003, s. 106. 
rodzaju podmiotów, ale też środkiem służącym rozszerzeniu sfery bezpośredniego uczestnictwa państwa w działalności gospodarczej, a w konsekwencji, ogólnie rzecz ujmując, środkiem „,antykryzysowym”, przy założeniu wszakże, że interwencja państwa w sferę własności pozwala zapobiegać lub osłabiać zjawiska kryzysowe w gospodarce. Tego typu nacjonalizacja to również środek służący umacnianiu i rozszerzaniu własnościowego sektora państwowego w gospodarce dla zapewnienia organom państwa wpływu na obsadę stanowisk menedżerskich, decydowania o strategii rozwojowej przedsiębiorstw, a nawet zmniejszania znaczenia zagranicznych przedsiębiorców (inwestorów) w gospodarce narodowej ${ }^{8}$.

W warunkach polskich nie ma obecnie aksjologicznej akceptacji podejmowania jakichkolwiek działań nacjonalizacyjnych. W kontekście prawa należy zauważyć, że - stosownie do przepisów Konstytucji RP — państwo powinno chronić własność i prawo dziedziczenia (art. 21 ust. 1), przy czym każdy (podmiot prawa) ma równe prawo do własności, innych praw majątkowych oraz prawo dziedziczenia, a własność może być ograniczona tylko ustawą i jedynie w zakresie, w jakim nie narusza ona istoty prawa własności (art. 64 ust. 1 i 3). Konstytucja nie posługuje się wcale określeniem „nacjonalizacja”, a zatem nie dopuszcza w ogóle tego rodzaju ingerencji w sferę własności, choć przewiduje możliwość wywłaszczenia na cele publiczne za słusznym odszkodowaniem (art. 21 ust. 2), czyli możliwość pozbawienia lub ograniczenia prawa własności lub prawa użytkowania wieczystego. Oczywiste jest wprawdzie, iż przepisy aktów nacjonalizacyjnych są nie do pogodzenia ze standardami prawnymi wynikającymi z Konstytucji ${ }^{9}$. W świetle Konstytucji RP traci jednak aktualność pytanie o zgodność aktów nacjonalizacyjnych z jej przepisami. Akty nacjonalizacyjne wydane zostały bowiem przed wejściem w życie Konstytucji RP, a ponadto ich przepisy znalazły zastosowanie do - niejako jednorazowego - uregulowania stosunków własnościowych w Polsce i tym samym skutek prawny tych przepisów został już „skonsumowany”"

Odrębną kwestią jest natomiast problem obowiązywania aktów nacjonalizacyjnych. Ponieważ nie zostały one formalnie uchylone, należy przyjąć, że nadal obowiązują i mogą znajdować zastosowanie do ustalania skutków zdarzeń zaistniałych w przeszłości. Zgodnie z utrwalonym w orzecznictwie Trybunału Konstytucyjnego poglądem utrata mocy obowiązującej przez akt normatywny następuje zresztą nie tyle z przyczyny czysto formalnej (uchylenie), ile wówczas, gdy nie może on zostać zastosowany w jakimkolwiek stanie faktycznym ${ }^{11}$. Skutki zdarzeń wynikłych z obowiązywania aktów nacjonalizacyjnych trwają, choć

8 Politycy i media wskazują na tak zwaną repolonizację.

9 Zob. np. uchwała Trybunału Konstytucyjnego (dalej: TK) z dnia 16 września 1996 r., W 15/95, OTK 1996, nr 2, poz. 13.

10 Tak Trybunał Konstytucyjny w postanowieniu z dnia 1 marca 2010 r., P 107/08, OTK-A 2010, nr 3, poz. 27.

11 Zob. m.in. wyrok TK z dnia 31 stycznia 2001 r., P 4/99, OTK 2001, nr 1, poz. 5; postanowienie TK z dnia 27 marca 1996 r., U 7/95, OTK 1996, nr 2, poz. 11. 
mają charakter nieodwracalny ${ }^{12}$, a podmioty, które skorzystały w dobrej wierze z możliwości nabycia mienia od państwa, są chronione zasadą ochrony praw słusznie nabytych ${ }^{13}$. Podkreśla się, że akty nacjonalizacyjne są tym samym obecne w systemie prawa aktualnego, za czym przemawia okoliczność, że wiele aktów prawnych, także wydanych po 1989 roku, odnosi się do nich, a wiele wyroków $\mathrm{i}$ innych rozstrzygnięć znajduje podstawę $\mathrm{w}$ przepisach nacjonalizacyjnych, które należy stosować do (w zakresie) oceny stanów faktycznych zrodzonych w efekcie zastosowania tych przepisów ${ }^{14}$.

Nacjonalizację uzasadniano potrzebami planowanej odbudowy gospodarki narodowej oraz zapewnienia państwu suwerenności gospodarczej i podniesienia ogólnego dobrobytu ${ }^{15}$. Wskazywano także, że nacjonalizacja ma usunąć pozostałości przywilejów obszarniczo-feudalnych ${ }^{16}$ lub że jest koniecznością państwową i gospodarczą ${ }^{17}$. W swej warstwie werbalnej, w języku polityki i medialnej propagandy, nacjonalizacja zmierzała do urzeczywistnienia sprawiedliwości społecznej poprzez wyeliminowanie z życia społecznego prywatnych właścicieli składników majątku zaangażowanego w gospodarkę i stworzenia społeczeństwa, w którym kapitał i własność środków produkcji nie miały decydować o pozycji społecznej jednostki.

Nacjonalizację uzasadniono również względami politycznymi, gdy przejęciu przez państwo (Skarb Państwa) podlegał majątek byłej Polskiej Zjednoczonej Partii Robotniczej ${ }^{18}$.

\section{REPRYWATYZACJA}

Reprywatyzacja to proces polegający na denacjonalizacji, a więc na dokonywaniu zwrotu mienia państwowego (lub mienia Skarbu Państwa) przejętego przez państwo (Skarb Państwa) od osób prywatnych w drodze nacjonalizacji19. Reprywatyzacja oznacza zatem przywracanie stanu poprzedniego w sferze stosunków

12 Tak we wskazanym w poprzednim przypisie wyroku i postanowieniu TK.

13 Zob. K. Osajda, Nacjonalizacja i reprywatyzacja, Warszawa 2009, s. 30-31.

14 Tak L. Garlicki w zdaniu odrębnym do postanowienia TK z dnia 28 listopada 2001 r., SK 5/01, OTK 2001, nr 8, poz. 266.

15 Tak art. 1 ustawy o przejęciu na własność Państwa podstawowych gałęzi gospodarki narodowej.

16 Tak preambuła ustawy o przejęciu przez Państwo dóbr martwej ręki, poręczeniu proboszczom posiadania gospodarstw rolnych i utworzeniu Funduszu Kościelnego.

17 Tak art. 1 ust. 1 dekretu o przeprowadzeniu reformy rolnej.

18 Ustawa z dnia 9 listopada 1990 r. o przejęciu majątku byłej Polskiej Zjednoczonej Partii Robotniczej (Dz.U. z 1991 r. Nr 16, poz. 72 ze zm.).

19 Zob. K. Osajda, op. cit., s. 15; K. Dobrzeniecki, M. Romanowski, Reprywatyzacja. Problemy tworzenia i stosowania prawa, Warszawa 2015, s. $10 \mathrm{n}$. 
własnościowych w wyniku (powtórnej) prywatyzacji mienia, którego podmiotami były uprzednio (przed nacjonalizacją) także podmioty prywatne ${ }^{20}$.

W Polsce po przeprowadzeniu nacjonalizacji - jeszcze w okresie oficjalnego uznawania jej przesłanek i celów za prawidłowe i zasadne - pojawiły się koncepcje dotyczące reprywatyzacji niektórych składników majątku ${ }^{21}$. Zostały one najpierw odzwierciedlone w aktach prawnych zakładających zwrot majątku kościelnym osobom prawnym oraz zwrot niektórych nieruchomości położonych na terenie miasta stołecznego Warszawa w drodze ustanowienia odrębnej własności lokali i budynków i oddanie gruntów w użytkowanie wieczyste byłym ich właścicielom ${ }^{22}$.

Nieruchomości państwowe lub ich części położone na obszarze ziem zachodnich i północnych, które znajdowały się w wyłącznym faktycznym władaniu kościelnych osób prawnych i związków wyznaniowych, przeszła nieodpłatnie na te podmioty. Przejście własności nastąpiło z mocy prawa i było wolne od podatków i opłat ${ }^{23}$. Prawo kościołów do zwrotu znacjonalizowanych nieruchomości w znacznie szerszym zakresie uwzględniono na podstawie ustaw regulujących stosunek państwa do poszczególnych kościołów ${ }^{24}$. W szczególności dotyczyło to Kościoła katolickiego, który ustawą ${ }^{25}$ został objęty procesem reprywatyzacji ${ }^{26}$.

W wypadku nieruchomości położonych na terenie Warszawy ich zwrot stał się możliwy w 1965 roku na mocy uchwały Rady Ministrów, która przewidywała oddanie niektórych terenów w wieczyste użytkowanie poprzednim właścicielom $^{27}$. Dotyczyło to jednak tylko nielicznych przypadków, w których zwrot pozostawał w zgodzie z założeniami zagospodarowania przestrzennego. Także

20 Zob. J. Szachułowicz, Zasady i organizacja reprywatyzacji, „Państwo i Prawo” (dalej: PiP) 2003, nr 9, s. 28 n.

${ }^{21}$ Zob. K. Dobrzeniecki, M. Romanowski, op. cit., s. 76 n. Podobnie w innych państwach, zob. K. Sobczak, Reprywatyzacja, „Przegląd Ustawodawstwa Gospodarczego” 2000, nr 1, s. 2 n.

22 Zob. ustawa z dnia 29 kwietnia 1985 r. o gospodarce gruntami i wywłaszczaniu nieruchomości (tekst jedn. Dz.U. z 1991 r. Nr 30, poz. 127 ze zm.); zob. także H. Golanowski, Problemy reprywatyzacji gruntów warszawskich w świetle aktualnie obowiąujacych przepisów prawa, „Monitor Prawniczy" (dalej: MP) 1998, nr 2, s. 45-49.

23 Zob. ustawa z dnia 23 czerwca 1971 r. o przejściu na osoby prawne Kościoła Rzymskokatolickiego oraz innych Kościołów i związków wyznaniowych własności niektórych nieruchomości położonych na Ziemiach Zachodnich i Północnych (Dz.U. Nr 16, poz. 156).

${ }^{24}$ Zob. m.in. ustawy: z dnia 4 lipca 1991 r. o stosunku Państwa do Polskiego Autokefalicznego Kościoła Prawosławnego (tekst jedn. Dz.U. z 2014 r. poz. 1726); z dnia 13 maja 1994 r. o stosunku Państwa do Kościoła Ewangelicko-Augsburskiego w Rzeczypospolitej Polskiej (tekst jedn. Dz.U. z 2015 r. poz. 43); z dnia 30 czerwca 1995 r. o stosunku Państwa do Kościoła Chrześcijan Baptystów w Rzeczypospolitej Polskiej (tekst jedn. Dz.U. z 2015 r. poz. 169 ze zm.). Zob. także P. Borecki, Reprywatyzacja nieruchomości na rzecz gmin wyznaniowych żydowskich, PiP 2011, nr 9, s. 61-73.

25 Zob. ustawa z dnia 17 maja 1989 r. o stosunku Państwa do Kościoła Katolickiego w Rzeczypospolitej Polskiej (tekst jedn. Dz.U. z 2013 r. poz. 1169 ze zm.).

26 Zob. K. Dobrzeniecki, M. Romanowski, op. cit., s. 97 n.

27 Uchwała Rady Ministrów nr 11 z dnia 27 stycznia 1965 r. w sprawie oddania niektórych terenów na obszarze m.st. Warszawy w wieczyste użytkowanie (M.P. Nr 6, poz. 18). 
w ograniczonym zakresie kwestia reprywatyzacji uregulowana została w ustawie z 1985 roku $^{28}$, ponieważ byli właściciele mogli na jej podstawie otrzymać zwrot tylko jednej nieruchomości z prawem jej użytkowania wieczystego. Na gruncie obowiązującej ustawy o gospodarce nieruchomościami ${ }^{29}$ prawo do zwrotu również wyłącznie jednej nieruchomości zachowali poprzedni właściciele, gdy ich uprawnienia do odszkodowania za utracone nieruchomości wygasły na podstawie ustawy z 1985 roku. Regulacja praw byłych właścicieli gruntów warszawskich oraz Skarbu Państwa została ostatnio przeprowadzona nowelizacją ustawy o gospodarce nieruchomościami ${ }^{30}$.

Zakładając potrzebę przeprowadzenia reprywatyzacji, należałoby — jak się wydaje - przede wszystkim określić krąg beneficjentów tego procesu. Zakres podmiotowy reprywatyzacji może jednak budzić wiele wątpliwości i zastrzeżeń, a w konsekwencji nie znajdować akceptacji jego odpowiedniego wytyczenia. W szczególności trzeba dostrzegać okoliczność (już wskazaną), iż osoby zagraniczne, które utraciły majątek w wyniku nacjonalizacji w Polsce, w wielu przypadkach otrzymały z tego tytułu odszkodowanie i w większym stopniu niż osoby krajowe zostały zaspokojone ${ }^{31}$. Czy zatem powinny one uczestniczyć w reprywatyzacji na równi z osobami krajowymi oraz czy zwrot na ich rzecz składników utraconego mienia lub wypłata dalszych odszkodowań będzie pozostawać w zgodzie z poczuciem sprawiedliwości społecznej, zważywszy, że odszkodowania zostałyby zapewne przekazane za granicę? Czy właściwy byłby zwrot majątków także następcom prawnym byłych właścicieli w kontekście zakazu pozbawiania jakiejkolwiek kategorii osób zdolności do dziedziczenia? Zakaz ten w świetle art. 31 ust. 3 Konstytucji RP nie ma jednak charakteru absolutnego ${ }^{32}$ i spod dziedziczenia możliwe byłoby ustawowe wyłączenie niektórych kategorii spadkobierców, na przykład spadkobierców wspólników spółek lub członków spółdzielni. Podobny dylemat dotyczy reprywatyzacji skierowanej do osób prawnych i jednostek organizacyjnych niebędących osobami prawnymi, a to z racji trudności w zakresie identyfikacji przekształconych lub nieistniejących już jednostek organizacyjnych,

28 Ustawa z dnia 29 kwietnia 1985 r. o gospodarce gruntami i wywłaszczaniu nieruchomości (tekst jedn. Dz.U. z 1991 r. Nr 30, poz. 127 ze zm.).

29 Ustawa z 21 sierpnia 1997 r. gospodarce nieruchomościami (tekst jedn. Dz.U. z 2016 r. poz. 2147 ze zm.).

${ }^{30}$ Ustawa z dnia 25 czerwca 2015 r. (Dz.U. z 2016 r. poz. 1271); zob. także K. Dobrzeniecki, M. Romanowski, op. cit., s.106 n.; oraz uwagi dotyczące nowelizacji wskazanej ustawy: M. Watrakiewicz, Kilka uwag o tzw. małej ustawie reprywatyzacyjnej, „Rejent” 2016, nr 10, s. 56-66.

31 W kwestii odszkodowań dla cudzoziemców zob. M. Muszyński, Nacjonalizacja mienia cudzoziemców w Polsce a problem rekompensaty za mienie pozostawione, „Przegląd Sądowy” 2006, nr 1, s. 43-75; zob. także M. Soszyńska, Polsko-amerykański uktad indemnizacyjny z dnia 16 lipca 1960 r. jako forma realizacji odpowiedzialności Polski za powojenna nacjonalizację mienia obywateli Stanów Zjednoczonych, „Prawo - Administracja - Kościół” 2005, nr 4, s. 119-137.

32 Zob. np. wyrok TK z dnia 31 stycznia 2001 r., P 4/99, OTK 2001, nr 1, poz. 5. 
lecz także personifikacji ich interesów majątkowych oraz interesów wspólników, założycieli lub członków tych jednostek ${ }^{33}$.

Również zakres przedmiotowy reprywatyzacji może wzbudzać kontrowersje choćby z tej racji, że część składników majątkowych, które mogłyby być przeznaczone na potrzeby reprywatyzacji, fizycznie nie istnieje albo uległy one znaczącemu zniszczeniu lub dekapitalizacji. W takich wypadkach niemożliwy lub utrudniony jest zwrot mienia w naturze, a w grę wchodzi jedynie rekompensata finansowa lub przekazanie osobie uprawnionej innego składnika majątku. Rekompensaty finansowe będące ekwiwalentem utraconych majątków stanowić mogą znaczne obciążenie budżetu państwa i w konsekwencji ich wysokość z przyczyn zarówno ekonomicznych, jak i społecznych musi podlegać istotnym ograniczeniom, przez co niewątpliwie utracą one walor odszkodowania ${ }^{34}$. Ponadto sporą część znacjonalizowanego mienia stanowiły zorganizowane kompleksy składników majątkowych pod postaciami przedsiębiorstw i gospodarstw rolnych, co sprawia, że trudno byłoby obecnie ustalić, jakie ich elementy składowe poza nieruchomościami mogłyby podlegać reprywatyzacji, ewentualnie jaka jest ich wartość ${ }^{35}$.

Można uznać, że na przeszkodzie podjęcia reprywatyzacji stanęła - przeprowadzana począwszy od 1990 roku i zakrojona na szeroką skalę przedmiotową i podmiotową - prywatyzacja. Koncepcja prywatyzacji w gospodarce uzyskała zarazem prymat nad koncepcją (koncepcjami) reprywatyzacji, a dokonania w zakresie prywatyzacji wykluczają możliwości reprywatyzacji majątku choćby z uwagi na zasadę ochrony praw nabytych w dobrej wierze. Reprywatyzacji polegającej na zwrocie mienia w naturze nie sprzyjają ponadto potrzeba ochrony takich dóbr, jak zabytki, względy bezpieczeństwa i obronności (w wypadku mienia wykorzystywanego na tego rodzaju potrzeby), a także potrzeby związane z ochroną środowiska (w przypadku zwrotu na przykład lasów). Jak już wskazano, sceptycznie należy oceniać również możliwości reprywatyzacji w drodze wypłaty rekompensat finansowych, a to głównie z powodu braku wystarczających środków na ten cel w budżecie państwa.

Wobec tego byli właściciele mogą ewentualnie pokładać nadzieję w zakrojonym na mniejszą skalę procesie reprywatyzacji, w ramach którego zwrotu mienia dokonuje się na podstawie orzeczeń sądowych kwestionujących przeprowadzoną uprzednio nacjonalizację. Tego rodzaju reprywatyzacja ma charakter indywidualny i konkretny zarazem, jako że orzeczenia dotyczą jedynie poszczególnych, jednostkowych przypadków.

Należy zauważyć, że wartością, do której można się odwołać, uzasadniając potrzebę reprywatyzacji, jest — podobnie jak w wypadku nacjonalizacji — spra-

33 Zob. w tej kwestii W.J. Katner, Uwarunkowania prawne reprywatyzacji w Polsce (zakres przedmiotowy i podmiotowy, roszczenia reprywatyzacyjne), PiP 2003, $\mathrm{nr} 7$, s. 25-26.

34 Por. W.J. Katner, op. cit., s. 25.

35 Zob. W.J. Katner, op. cit., s. 17-32; J. Forystek, Dochodzenie roszczeń reprywatyzacyjnych w świetle orzecznictwa sądów cywilnych i administracyjnych oraz Trybunalu Konstytucyjnego, MP 2011, nr 21, s. 1133-1144. 
wiedliwość społeczna. W tym jednak przypadku wartość ta powinna być odnoszona do sytuacji, w której dochodzi do zwrotu składników majątku lub wypłaty odpowiednich rekompensat na rzecz byłych właścicieli (lub ich następców prawnych), którzy utracili majątek w wyniku nacjonalizacji, a zatem przywrócony zostaje ład społeczny oparty na poszanowaniu prywatnej własności i ochronie tej własności.

\section{UWŁASZCZENIE I KOMUNALIZACJA}

Zupełnie inny charakter miały dwa podobne w swej treści i znaczeniu procesy dotyczące przekształceń własnościowych - uwłaszczenie państwowych osób prawnych i komunalizacja. Uwłaszczenie prowadziło do uznania przede wszystkim, iż państwowe osoby prawne - poczynając od przedsiębiorstw państwowych - mogą być i są podmiotami praw i obowiązków majątkowych, w szczególności prawa własności i innych praw rzeczowych, a następnie do przekazania tym podmiotom prawa własności i prawa użytkowania wieczystego w odniesieniu do konkretnych składników majątku pozostającego w ich dyspozycji. Była to zatem akceptacja rozdzielenia praw między Skarb Państwa i państwowe osoby prawne, a zarazem „odstąpienie” przez państwo na rzecz państwowych osób prawnych prawa własności, lecz także uznanie podmiotowości i samodzielności tych osób. Jednocześnie należy zauważyć, że państwowe osoby prawne rzeczywiście nabyły odpowiednie składniki majątku dopiero na mocy noweli do ustawy o gospodarce gruntami.

Omówione uwłaszczenie państwowych osób prawnych stało się przesłanką realizacji koncepcji prywatyzacji przedsiębiorstw państwowych. Aby można było ich majątek zbyć osobom prywatnym, konieczne stało się uprzednie upodmiotowienie tych przedsiębiorstw w sferze stosunków własnościowych i ustalenie, że znajdujące się w ich gestii składniki majątku są objęte prawem własności lub użytkowania wieczystego ${ }^{36}$.

Uwłaszczenie niewątpliwie doprowadziło do wzmocnienia pozycji prawnej przedsiębiorstw państwowych oraz do określenia granic ich autonomii w obszarze praw majątkowych, w tym rzeczowych. Dla tych przedsiębiorstw państwowych, które nie zostały wytypowane na samym początku do prywatyzacji, uwłaszczenie mogło stać się (choć nie zawsze) podwaliną samodzielnego, opartego na rachunku ekonomicznym, efektywnego gospodarowania składnikami majątku.

Uwłaszczenie oznaczało również rezygnację państwa z „monopolu” na własność państwową. W stosunkach własnościowych zamiast państwa zaczął występować Skarb Państwa i równoprawne mu państwowe osoby prawne ${ }^{37}$.

36 Zob. w tej kwestii T. Adamski, Uwłaszczenie przedsiębiorstw państwowych a problemy zwiazane z ich prywatyzacja, „Prawo Spółek” 1999, nr 11, s. 39-42.

37 Por. T. Rabska, Prawny mechanizm kierowania gospodarka, Wrocław-Warszawa-Kraków 1990, s. 19 n.; zob. także B. Popowska, Przedsiębiorstwa państwowe po zmianach ustrojowych 
Podobny do uwłaszczenia charakter miała komunalizacja mienia państwowego. Ona także oznaczała rezygnację przez państwo z wyłączności w zakresie skupiania wszelkich praw i obowiązków dotyczących mienia ogólnonarodowego (państwowego) i przekazanie części tego mienia samorządom terytorialnym. Komunalizacja w efekcie polegała na upodmiotowieniu samorządów (gmin) w sferze stosunków własnościowych i przyznania im praw i obowiązków odnoszących się do nowej kategorii mienia - mienia komunalnego. Kategoria ta przestała istnieć w związku z przejęciem przez państwo majątków istniejących jeszcze w 1950 roku związków samorządu terytorialnego ${ }^{38}$, a jej reaktywacja nastąpiła w 1990 roku $^{39}$.

Komunalizacja doprowadziła do wzmocnienia zarówno samodzielności ekonomicznej jednostek samorządu terytorialnego, jak i — w konsekwencji — ich samorządności, co w sumie wpłynęło znacząco na pozycję prawną, ekonomiczną i społeczną tych jednostek w strukturach państwa.

\section{PRYWATYZACJA}

Jak już wskazano, przekształcenie własnościowe polegające na tak zwanym uwłaszczeniu przedsiębiorstw państwowych stało się przesłanką dokonania kolejnego przekształcenia, sprowadzającego się do prywatyzacji wymienionych podmiotów. Prywatyzację można potraktować przy tym jako sui generis kontynuację uwłaszczenia, a więc procesu, który doprowadził do upodmiotowienia w sferze mienia państwowego przedsiębiorstw państwowych. Prywatyzacja oznacza bowiem zadysponowanie - na rzecz osób prywatnych (niepublicznych) — przedmiotem praw majątkowych uwłaszczonych przedsiębiorstw, przy czym owo zadysponowanie stało się możliwe jedynie w sytuacji uzyskania przez przedsiębiorstwa statusu autonomicznych podmiotów mienia państwowego.

Idea prywatyzacji w Polsce zrodziła się i zaczęła podlegać realizacji wraz ze zmianami ustrojowymi zapoczątkowanymi w 1989 roku. Zakładała ona dokonanie zmian w sferze własności poprzez doprowadzenie do zbycia praw przez przedsiębiorstwa państwowe i nabycia ich przez osoby prywatne. Nie łączono natomiast prywatyzacji z ewentualnym zbyciem praw do majątku przez Skarb Państwa. Formułowane koncepcje prywatyzacji kładły akcent na różne aspekty tego procesu, w tym na okres jego realizacji, zakres podmiotowy i przedmiotowy, zróżnicowanie form i procedur prywatyzacji. Sięgano przy tym do wzorów

w Polsce, [w:] Gospodarka. Administracja. Samorzad, red. H. Olszewski, B. Popowska, Poznań 1997, s. 399 n.

$38 \mathrm{Na}$ mocy art. 32 ust. 2 ustawy z dnia 20 marca 1950 r. o terenowych organach jednolitej władzy państwowej (Dz.U. Nr 14, poz. 130 ze zm.).

39 Na mocy art. 43 n. ustawy z dnia 8 marca 1990 r. o samorządzie terytorialnym (Dz.U. Nr 16, poz. 95 ze zm.) i art. 5 n. ustawy z dnia 10 maja 1990 r. - Przepisy wprowadzające ustawę o samorządzie terytorialnym i ustawę o pracownikach samorządowych (Dz.U. Nr 32, poz. 191 ze zm.). 
wypracowanych w innych krajach, na przykład Wielkiej Brytanii, wskazując na potrzebę prywatyzacji w szerokim zakresie, jednak powolną i dokładną (ang. case by case) lub - według innego wariantu — szybką, niemal jednorazową. Sugerowana była także prywatyzacja tylko częściowa i pozostawienie dużego sektora państwowego w gospodarce, w ramach którego funkcjonowałyby przedsiębiorstwa państwowe, choć skomercjalizowane, przekształcone w spółki prawa handlowego. Wskazywano również na prywatyzację sprowadzającą się jedynie do przekształcenia przedsiębiorstw państwowych w spółki Skarbu Państwa, w których część akcji przekazano by pracownikom (akcjonariat pracowniczy). Pojawiła się również koncepcja tak zwanej powszechnej prywatyzacji, a więc obejmującej wszystkich obywateli Polski, którą łączono z emisją bonów prywatyzacyjnych uprawniających do nabycia akcji spółek Skarbu Państwa ${ }^{40}$.

Przyjmuje się, że prywatyzacji przyświecają określone — niekiedy jednoznacznie i wprost, ale częstokroć jedynie implicite — cele. Są nimi w szczególności: zwiększenie efektywności i konkurencyjności podmiotów działalności gospodarczej, zapewnienie ich rozwoju, dokapitalizowanie, zwiększenie liczby zatrudnionych, zapewnienie przedsiębiorstwu nowych rozwiązań technologicznych, otwarcie na nowe rynki zbytu ${ }^{41}$. Prywatyzacja dokonywana jest także niejako „dla zasady" i stanowi wówczas cel sam w sobie. Przeprowadzana jest także w celu stricte fiskalnym — dla zapewnienia odpowiednich wpływów do budżetu państwa $\mathrm{z}$ racji przeprowadzonej prywatyzacji ${ }^{42}$. Wówczas może pozostawać w opozycji do wcześniej wykazanych celów i z punktu widzenia racjonalności działania nie zapewniać wymiernych efektów. W praktyce występują przypadki prywatyzacji, która w efekcie prowadzi do zakończenia lub znacznego ograniczenia działalności gospodarczej. Jest to związane przykładowo z nierealizowaniem zobowiązań nabywcy względem przedsiębiorstwa, a także z przejęciem przedsiębiorstwa przez podmiot znajdujący się w trudnej sytuacji ekonomicznej.

W 2017 roku ustawodawca zdecydował o pozostawieniu w mocy przepisów znowelizowanej ustawy z 30 sierpnia 1996 roku ${ }^{43}$ odnoszących się do komercjalizacji. Komercjalizacja obejmuje swoim zakresem czynności mające dokonać zmiany o charakterze organizacyjnym, które sprowadzają się do przekształcenia przedsiębiorstwa państwowego w spółkę. Jest to spółka kapitałowa prawa handlowego, a więc spółka z ograniczoną odpowiedzialnością lub spółka akcyjna.

Przeprowadzenie komercjalizacji otwiera drogę do rozpoczęcia drugiego etapu, w ramach którego dokonuje się zbywania akcji lub udziałów jednoosobowej spółki Skarbu Państwa. Jeśli zatem komercjalizacja, jak wskazano, wiąże się

40 Zob. na ten temat M. Federowicz, Wpływ prywatyzacji i przekształceń własnościowych w gospodarce polskiej na stosunki przemystowe, „Polityka Społeczna” 1997, nr 2, s. 1-8.

41 Zob. np. W.J. Katner, Komercjalizacja i prywatyzacja. Komentarz, Warszawa 2003, s. 11.

42 Zob. K. Sobczak, op. cit., s. 361.

43 Ustawa z dnia 30 sierpnia 1996 r. o komercjalizacji i niektórych uprawnieniach pracowników (tekst jedn. Dz.U. z 2017 r. poz. 1055). 
z przekształceniem organizacyjnym danego podmiotu działalności gospodarczej (przedsiębiorstwa państwowego), to zbywanie akcji lub udziałów oznacza dokonywanie przekształcenia o charakterze własnościowym.

\title{
UWAGI KOŃCOWE
}

Można, jak się zdaje, przyjąć, że dokonywanie poszczególnych przekształceń własnościowych niezależnie od nadawanych im celów i przypisywanych wartości uzasadniających owe przekształcenia w ostatecznym rozrachunku zmierzało do osiągnięcia wymiernych efektów ekonomicznych, a zarazem do wykazania skuteczności państwa w obszarze kształtowania ustroju gospodarczego, w tym w szczególności stosunków własnościowych. Przesłanki przeprowadzania przekształceń kształtowane były wprawdzie w sposób różny, każdorazowo mieściły się one jednak w ogólnej kategorii interesu publicznego, który inaczej był wypełniany treścią $\mathrm{w}$ okresie nacjonalizacji, inaczej zaś $\mathrm{w}$ czasie przeprowadzania denacjonalizacji.

\section{AXIOLOGY AND LAW OF POSSESSIONAL TRANSFORMATIONS IN ECONOMY}

\author{
Summary
}

The possessional transformations have mainly subjective character, depending first of all on "replacing" the definite subjects of right of property by other subjects. The forms of possessional transformations are nationalization and its consequences, and so to say reverse: reprivatization, affranchisement, municipalisation and privatization. Each of these forms is connected with undertaking legal and actual actions, the aim of which is the induction of suitable change of subject of the property right. The basis of these actions are acts of law with legal ranks introducing the obligation - being actualized in the course of a suitable procedure - taking over of the property right from the existing owner (owners). In each case of performing the possessional transformation, formulated - in clear way or inferred - the premise or the aim of transformation, in peculiarity is then the public business which is given diverse content and the meaning. Not only however generally comprehended and not always identified public business is the premise of making of possessional transformations. The basis of those transformations are different kind of values of the character both legal and economic as well as social and as a consequence there were and still are different motives (premise) of their making.

Keywords: possessional transformation, nationalization, reprivatization, municipalization, franchisement, privatization, public business 


\section{BIBLIOGRAFIA}

Adamski T., Uwłaszczenie przedsiębiorstw państwowych a problemy zwiąane z ich prywatyzacja, „Prawo Spółek” 1999, nr 11.

Borecki P., Reprywatyzacja nieruchomości na rzecz gmin wyznaniowych żydowskich, „Państwo i Prawo" 2011, nr 9.

Dobrzeniecki K., Romanowski M., Reprywatyzacja. Problemy tworzenia i stosowania prawa, Warszawa 2015.

Federowicz M., Wplyw prywatyzacji i przekształceń własnościowych w gospodarce polskiej na stosunki przemystowe, „Polityka Społeczna” 1997, nr 2.

Forystek J., Dochodzenie roszczeń reprywatyzacyjnych $w$ świetle orzecznictwa sadów cywilnych i administracyjnych oraz Trybunału Konstytucyjnego, „Monitor Prawniczy” 2011, nr 21.

Golanowski H., Problemy reprywatyzacji gruntów warszawskich w świetle aktualnie obowiazujacych przepisów prawa, „Monitor Prawniczy” 1998, nr 2.

Ignatowicz J., Stefaniuk K., Prawo rzeczowe, Warszawa 2003.

Katner W.J., Komercjalizacja i prywatyzacja. Komentarz, Warszawa 2003.

Katner W.J., Uwarunkowania prawne reprywatyzacji w Polsce (zakres przedmiotowy i podmiotowy, roszczenia reprywatyzacyjne), „Państwo i Prawo” 2003, nr 7.

Muszyński M., Nacjonalizacja mienia cudzoziemców w Polsce a problem rekompensaty za mienie pozostawione, „Przegląd Sądowy” 2006, nr 1.

Osajda K., Nacjonalizacja i reprywatyzacja, Warszawa 2009.

Popowska B., Przedsiębiorstwa państwowe po zmianach ustrojowych w Polsce, [w:] Gospodarka. Administracja. Samorzad, red. H. Olszewski, B. Popowska, Poznań 1997.

Powałowski A., Przekształcenia własnościowe w gospodarce jako przejaw interwencjonizmu państwowego, „Gdańskie Studia Prawnicze” 22, 2009.

Powałowski A., Wybrane zagadnienia filozofii prawa gospodarczego publicznego, „Gdańskie Studia Prawnicze" 18, 2007.

Rabska T., Prawny mechanizm kierowania gospodarka, Wrocław-Warszawa-Kraków 1990.

Sobczak K., Reprywatyzacja, „Przegląd Ustawodawstwa Gospodarczego” 2000, nr 1.

Soszyńska M., Polsko-amerykański układ indemnizacyjny z dnia 16 lipca 1960 r. jako forma realizacji odpowiedzialności Polski za powojenna nacjonalizację mienia obywateli Stanów Zjednoczonych, „Prawo - Administracja - Kościół” 2005, nr 4.

Szachułowicz J., Zasady i organizacja reprywatyzacji, „Państwo i Prawo” 2003, nr 9.

Trzaskowski R., Nieodwracalne skutki prawne wadliwej decyzji nacjonalizacyjnej. Przedstawienie dorobku orzecznictwa i doktryny, „Kwartalnik Prawa Publicznego” 2003, nr 3.

Watrakiewicz M., Kilka uwag o tzw. małej ustawie reprywatyzacyjnej, „Rejent” 2016, nr 10.

Przegląd Prawa i Administracji 114, 2018

(C) for this edition by CNS 